\title{
Стратегічні комунікації у науково-теоретичному дискурсі
}

\author{
Терещеня О. В.
}

\section{Дніпровський національний університет імені Олеся Гончара}

Поняття «стратегічні комунікації» відносно недавно стало популярним у сфері соціальних комунікацій. На початку 2000-х рр. цим терміном послуговувалися переважно у військових, політичних та наукових колах США та деяких європейських країн. Наразі налічується велика кількість досліджень стратегічних комунікацій, це поняття активно починають використовувати в наукових працях та офіційних нормативних документах як у світі, так і в Україні, однак загальноприйнятого визначення того, що являють собою стратегічні комунікації, як цей системний комплекс має студіюватися у спеціальних роботах та що $є$ їх кінцевою метою, допоки не існує. Це породжує певні непорозуміння та дискусії навколо навіть базових складових цього теоретико-практичного феномену. У статті розглянуто існуючі концепції стратегічних комунікацій, основні функції $\mathrm{i}$ компоненти поняття, здійснено аналіз окремих міркувань дослідників, запропоновано узагальнене тлумачення терміна. Систематизовано основні підходи до визначення стратегічних комунікацій, виокремлено їхні характеристики. Підкреслено окремі завдання, що необхідно розв'язати під час підготовки ефективної програми стратегічних комунікацій. Визначено, що елементи стратегічних комунікацій складаються з об'єктів стратегії, теорії комунікації та методу. Доведено, що ефективна система стратегічних комунікацій $€$ релевантним показником успішної діяльності організації та реалізації політичної програми, сприяє розвитку інститутів і гарантує підтримку суспільства в кризові моменти. Наголошено на тому, що однією з головних засад стратегічних комунікацій $\epsilon$ сприяння реалізації інтересів держави, організації чи компанії, натомість відсутність систематичного підходу, неефективна діяльність головних учасників процесу і нестабільна реалізація організаційних чи політичних стратегічних рішень зменшують вплив механізму організації чи державного управління загалом.

Ключові слова: стратегічні комунікації; сочіальні комунікації; науковий дискурс.

\section{1.Вступ}

Постановка проблеми. На сучасному етапі розвинені країни перебувають у постійному пошуку нових засобів для просування власних інтересів на світовій арені. Хоча термін «стратегічні комунікації» було введено в обіг у 1960-х рр., поняття до сьогодні потребує дослідження та розвитку. Ефективне використання основних інструментів стратегічних комунікацій дозволяє сформувати послідовну програму, що передбачає створення й оприлюднення повідомлень, які не лише містять важливу інформацію, але й мають вагомий вплив на аудиторію. Стратегічні комунікації передбачають створення перспективних стосунків між різноманітними суб'єктами, керівництвом та колективом, медіа та аудиторією, владою та суспільством на довготривалий термін.

Враховуючи той факт, що наразі ефективна зовнішня та внутрішня політика $€$ необхідними складовими для просування національних інтересів України, дослідження системи стратегічних комунікацій як складової політичного та соціального дискурсу $€$ перспективним напрямком.

До початку XXI ст. термін «стратегічні комунікації» використовувався переважно в мілітаризованих колах. У
2015 р. керівництво країн-членів ЄС почало розробляти Глобальну зовнішньополітичну стратегію розвитку та безпеки. У 2016 р. було ухвалено документ «Спільне бачення, спільні дії: сильніша Європа» (EU Global Strategy "Shared Vision, Common Action: A Stronger Europe», EUGS) [1]. Ця стратегія наголошує на спільних інтересах та окреслює напрямок подальшого руху. В ній презентуються основні компоненти зовнішньої політики Європейського Союзу, а саме: боротьба з тероризмом, безпека, енергетична безпека, кібербезпека і стратегічні комунікації. Найменш дослідженими як на теоретичному, так і на практичному рівні зовнішньої політики й безпеки $€ C$ стали саме стратегічні комунікації, які сприяють появі нових рівнів комунікації, ідеологічно відмінних від уже наявних. Комунікація виходить за національні, етнічні, ментальні та культурологічні межі, вимагає створення відповідної нормативно-правової системи, яка повинна узгоджувати інтереси суб'єктів інформаційного простору на глобальному рівні [2]. Стратегічні комунікації перетворюються на одну зі складових системи сучасної цивілізації, а їх адаптація до комунікативної структури $€$ необхідною для ефективного розвитку суспільства і процесів подальшого державотворення.
Tereshchenia O., Ph. D. Student of the Department of Mass and International Communication, e-mail address: Oxanater95@gmail.com, tel.: +380936231196,

ORCID: https://orcid.org/0000-0002-4886-1614,

Oles Honchar Dnipro National University,

13, Naykova Str., Dnipro, 49050, Ukraine
Терещеня О. В., аспірантка кафедри масової та міжнародної комунікачії, електронна адреса: Oxanater95@gmail.com, тел.: +380936231196, ORCID: https://orcid.org/0000-0002-4886-1614, Дніпровський начіональний університет імені О.Гончара, вул. Наукова, 13, Дніпро, 49050, Україна 
Нині дослідження стратегічних комунікацій на українському рівні знаходяться на початковому етапі i здебільшого орієнтуються на досвід Стратегічного командування США (U.S. Strategic Command) і стандарти НАТО щодо цієї проблематики: тобто мають опосередковане відношення до інтересів України та її державної ідентичності. Втім, у практичній площині термін активно використовується, наприклад, в офіційних документах, а саме - у дорожній карті Програми партнерства між Україною та НАТО [3], що була підписана у 2015 р., і у Воєнній доктрині України [4]. Також в освітньо-науковій сфері впроваджуються відповідні програми [5].

Аналіз останніх досліджень та публікацій. Дослідженням феномена стратегічних комунікацій займалися як зарубіжні, так і вітчизняні науковці, серед них: В. Ліпкан, Г. Почепцов, О. Кушнір, Л. Берк, С. Патерсон, О. Баровська, В. Ландсман та інші.

Більшість науковців погоджується, що стратегічні комунікації як інструмент досягнення мети використовуються в широкому спектрі інститутів. Вдала стратегія комунікації необхідна як у діяльності локальних організацій чи великих корпорацій, так і в побудові міжнародних відносин і управлінні державою. Саме тому важко підібрати єдине універсальне значення та пояснення такого широкого поняття [6, с. 10]. Спроба дати універсальне визначення даного феномена була здійснена у колективній публікації «Визначення стратегічної комунікації». Автори дослідження - Д. Верчіч, Б. Рулер, К. Шрірамеш, К. Халлахан, Д. Хольцхаузен наголошують на тому, що «стратегічні комунікації передбачають взаємодію різних акторів зі спрямованою практикою комунікації 3 метою досягнення інтересів організації» [7]. При цьому М. Толедано зауважує, що стратегія не ототожнюється 3 маніпуляцією і пропагандою, а, навпаки, використовує миролюбні засоби. Однак стратегічні комунікації у воєнних питаннях нерідко містять агресію, неоднозначні гасла та неетичні методи [8]. 3 іншого боку, Б. Гамільтон у рецензії на працю Дж. Фарвела «Переконання та сила: мистецтво стратегічних комунікацій» розглядає стратегічні комунікації як «вплив на масову свідомість 3 використанням слів, зображень, символів та дій для досягнення встановлених цілей і розуміння політичних інтересів» [9].

Українське наукове осмислення стратегічних комунікацій починається 3 дослідження Г. Почепцова «Стратегічні комунікації в політиці, бізнесі та державному управлінні» [10]. Щодо більш сучасних матеріалів, можемо виділити праці А. Баровської, в яких досліджуються стратегічні комунікації НАТО [11]. С. Соловйов окреслив основні характеристики стратегічних комунікацій [12]. Участь стратегічних комунікацій у формуванні української державності досліджується в працях О. Кушніра [13].

Мета дослідження - систематизувати існуючі підходи до визначення стратегічних комунікацій.

Об'єкт вивчення - поняття «стратегічних комунікацій» у сучасному науковому дискурсі.
Методи дослідження. Дослідження будується на визначенні теоретико-методологічних засад стратегічних комунікацій. Аналізуються основні характеристики стратегічних комунікацій в контексті історично-наукового дискурсу. Здійснюється порівняльний аналіз вже проведених досліджень, порівняння, проводиться виокремлення спільних характеристик феномену «стратегічні комунікації».

Аналіз демонструє, що зазначений феномен передбачає об'єднання всіх ключових акторів у сфері формування та реалізації державної політики та інформаційних відносин з метою створення позитивного впливу, розвитку держави, її окремих установ, організацій та членів суспільства, що створює механізм, який ми розглядаємо як сегмент стратегічних комунікацій. Виходячи з цього, за основу дослідження беруться стратегічні комунікації держави. Варто зазначити, що як у діяльності різних державних органів, насамперед урядових, оборони та національної безпеки, так і в установчій сфері підприємств та громадських організацій термін "стратегічні комунікації» має різне значення, розуміння, змістове навантаження та практичне функціонування. Вибір матеріалів для проведення дослідження, які ілюструють трансформацію поняття стратегічних комунікацій, спирається на структурнофункціональний аналіз дефініції, що дає можливість визначити аспекти узагальнення. Описовий метод, який $€$ стрижневим у даному дослідженні, використано задля комплексного огляду існуючих напрямків вивчення зазначеної проблематики.

\section{2. Результати дослідження}

До історії питання. Спочатку поняття стратегічних комунікацій згадувалося переважно у військових документах США. Наближена ж до теперішнього розуміння значення цього феномена дефініція з'являється на початку 2000-х рр. Дискусія щодо визначення i тлумачення поняття стратегічних комунікацій і їх вихід на системний рівень розпочалася під час президентства Дж. Буша молодшого. У 2002 р. створюється Координаційний комітет 3 політики стратегічних комунікацій в межах Ради національної безпеки США. Діяльність цієї організації передбачала співпрацю усіх агентств 3 американським урядом і президентом. Досягненням цього комітету стала «Національна стратегія США щодо стратегічних комунікацій у публічній дипломатії» від 2007 р. [14].

Проаналізувавши основні праці 3 теорії масових комунікацій, можемо визначити, що поняття стратегічних комунікацій, як ми розуміємо його зараз, з'являється вже після 2006 р. На цьому етапі питаннями геополітичних інтересів США займалася секретар Державного департаменту США К. Райс. Політичні рішення комітету розглядалися дипломатичними установами, а діяльність секретаря Держдепартаменту США набувала широкого розповсюдження, що сприяло підвищенню впливу США на внутрішню та зовнішню політику різних країн та міжнародні відносини загалом. 
У «Національній програмі для стратегічної комунікації», що була представлена президентською адміністрацією Конгресу США у 2010 р., стратегічні комунікації складаються з синхронізації сприйнятяя інформації і політичних дій у суспільстві, політичної дипломатії, комунікації за допомогою інформаційних компаній та засобів зв'язку з громадськістю [15]. Згодом цей документ оновлювався, з'явилися нові пункти та функції. Так, сьогодні стратегічні комунікації передбачають створення позитивного сприйняття світової спільноти з метою подальшого досягнення цілей зовнішньої політики США. Це вимагає створення ефективного плану, збільшення потенціалу держави, використання останніх технологій для покращення функціонування міжнародних організацій, розвитку дипломатичних служб тощо [16]. Діяльність управління стратегічних комунікацій США спрямована на відбір та аналіз подій, що подаються у засоби масової інформації внутрішньої та закордонної спільноти, його функціонування підтримується за допомогою Бюро 3 міжнародної безпеки і нерозповсюдження.

Під час президентства Б. Обами було створено Центр антитерористичних стратегічних комунікацій, що спрямований на розробку ефективної стратегії боротьби з дезінформацією про США та терористичною пропагандою в засобах масової інформації [17].

У 2015 р. щорічне звернення президента США «Про становище країни» (2015 State of the Union Address) було оприлюднене в мережі Інтернет. Таким чином, важливий політичний документ було представлено у загальному доступі з можливістю коментувати актуальні питання міжнародної політики. Це можна вважати новою, більш відкритою та доступною для народу формою стратегічних комунікацій [18]. Але при цьому більшість громадян США вважають, що акаунт Д. Трампа у Twitter потрібно закрити через агресивний зміст його публікацій, що породжує багато дискусій та критики.

Для $Є C$ стратегічні комунікації також не $€$ новим терміном. Згідно з висновками дослідників Королівського інституту міжнародних відносин (Chatham House), що були оприлюднені у звіті «Стратегічні комунікації та національна стратегія» від 2011 р., стратегічні комунікації «складаються 3 чотирьох основних компонентів: інформаційні операції, психологічні операції, публічна дипломатія та громадські дії. Ці компоненти, - зазначається у звіті, - мають спільні риси. По-перше, це необхідність інформувати, впливати та переконувати аудиторію всередині країни та за кордоном, враховуючи усі настрої громадськості. По-друге, - потреба в координації між урядами, щоб запобіти тому, що армія США називає "інформаційним братовбивством". По-третє, необхідність стратегічної комунікації сама по собі залежить від здатності повідомляти про дії усім дотичним та зацікавленим аудиторіям і забезпечувати доступність самих дій, які за природою доповнюють та підтримують стратегічні комунікації» [18, с. 3-4]. Самі ж стратегічні комунікації у звіті визначаються як «систематичні, узгоджені, послідовні та ефективні дії, що здійснюються на тактичному та оперативному рівні, сприяють розумінню цільової аудиторії і визначають, які канали більше підходять для розповсюдження певних типів поведінки» [Там само].
До визначення поняття. Стратегічні комунікації визначаються як область, що розвивається в галузі соціальних наук про комунікації та управління. Визначення цього понятя базуються на визначеннях таких понять, як «стратегія» та «комунікація». Г. Томас та К. Стефенс у процесі визначення концептотворчих чинників стратегічних комунікацій у своїй праці «Вступ до стратегічної комунікації» апелюють до праць Аргента, Хоуела та Бека, які визначають стратегічні комунікації як «узгоджену та загальноприйняту стратегію організації для покращення її стратегічного позиціонування» [19, р. 4]. Також автори визначають, що Грунинг наголошує на тому, що «стратегічні комунікації $€$ тією ланкою, що налагоджує діяльність між інституційними організаціями» [Там само]. Халлахан, Хольтгаузен, Верчич, ван Рулер та Шрірамеш дають визначення стратегічних комунікацій як «цілеспрямованого використання організацією комунікації з метою виконання своєї місії» [Там само].

Складові стратегічних комунікацій складаються з об'єктів стратегії, теорії комунікації та методу. Поняття «стратегія управління» не має сталого визначення. Джемісон розуміє під стратегічним менеджментом «процес, що допомагає менеджерам складних організацій розробляти i використовувати стратегію для узгодження компетенцій своєї організації, можливостей та обмежень у навколишньому світі. Другий компонент - це теорія комунікації, що налічує багато теорій, які комунікативісти використовують для вивчення різноманітних явищ. Виокремлюють теорію структуризації, критичну теорію, комунікативну конструкцію організацій, особисту та організаційну ідентифікацію. Третій компонент складається з методу дослідження, що передбачає аналітичні підходи комунікації, такі як риторичний та наративний аналіз, аналіз бесіди, соціальних мереж та семантично-мережевий аналіз» [Там само].

Комунікативну складову у даному аспекті обґрунтовують та пояснюють А. Редінг, К. Уід та Дж. Чез у статті «Концепція стратегічних комунікацій НАТО та її актуальність для Франції». Дослідники вважають, що стратегічні комунікації це процес з координації комунікацій між суб'єктами різних відомств та організацій, який передбачає певні слова та дії для підсилення стратегічного ефекту. Для досягнення поставленої мети використовуються різноманітні методи та вже існуючий досвід. Метою стратегічних комунікацій $€$ вплив на поведінку аудиторії з метою покращення позицій акторів і тим самим формувати їхнє інформаційне середовище $[20$, с. 10]. При цьому командна структура стратегічних комунікацій являє собою три рівні відповідальності, перші два з яких є стратегічними, а третій оперативно-тактичним. На першому етапі в штаб-квартирі НАТО визначаються повідомлення про головні цілі об'єднання. На другому рівні ці повідомлення передаються у Верховні штаб-квартири союзних держав Європи. I на третьому етапі розроблені повідомлення поширюються серед аудиторії в усній, письмовій формі та поведінковій комунікації [20, с. 15]. Ми можемо припустити, що даний алгоритм $€$ дієвим не лише у структурі НАТО, а й, за умови певної оптимізації, може застосовуватися у якості універсального у системі державотворення. При цьому слід 
враховувати той факт, що стратегічні комунікації - це комплекс розумової діяльності та ефективних дій, що передбачає розміщення комунікації в основі стратегії, тобто діяльність орієнтована на інформацію, яка передається різній аудиторії через узгоджені слова, образи та вчинки. Процес передачі інформації на сьогодні відбувається усіма доступними каналами, серед яких усе більшу роль відіграють кіберпростір та новітні технології. Ïх використовують для координації дій, передачі інформації, а також для аналізу навколишнього середовища з метою визначення та оцінки потенційних загроз. Кіберпростір також використовується під час конфлікту з метою визначення та впливу на комунікаційні системи супротивника. Інтернет та соціальні медіа часто використовуються для пропаганди, операцій впливу та інформаційної війни. Це може відчутно змінити думку та ставлення цільової аудиторії до подій, що відбуваються. По суті, це досить дієвий спосіб маніпулювання уявленнями суспільства з метою викликати руйнівну поведінку в реальному житті (див. детальніше: [21, с. 104]).

Узагальнюючи існуючі підходи до визначення стратегічних комунікацій, виокремимо їх основні характеристики:

- головною метою $€$ визначення та досягнення інтересів держави на національному і міжнародному рівні;

- ефективна взаємодія та плідна співпраця між політиками та активістами для досягнення спільної мети;

- встановлення довірливих стосунків 3 аудиторією, забезпечення інформацією та підтримка зворотного зв'язку;

- здатність зважати на потреби аудиторії та вивчати реакції на ті чи інші події та повідомлення;

- можливість тлумачення дій як інформації, зворотного зв'язку;

- налагодження діяльності між інституційними організаціями;

- цілеспрямоване використання організацією з метою виконання своєї місії;

- координація комунікацій між суб'єктами різних організацій для посилення стратегічного ефекту;

- покращення позицій головних акторів;

- формування інформаційного середовища.

Найголовнішим завданням стратегічних комунікацій, на думку А. Баровської, $€$ вплив на аудиторію, збільшення кількості прихильників тієї чи іншої позиції. Залучення аудиторії відбувається на різних рівнях завдяки спеціальним технологіям та заходам [11]. У своїй праці «Комунікативні правила підходу до організаційної культури» М.Шел наголошує на тому, що група може являти собою цілісну та сильну культуру тією мірою, в якій її представники поділяють свої очікування, що базуються на отриманому досвіді та відповідають системі загальних цінностей [22].

У розвинутих країнах компанії та організації більш уваги приділяють розвитку мережевих структур, що містять у собі не тільки інституційні установи, але й критичні та неформальні групи споживачів. Це забезпечує міцні стабільні відносини і стійку позицію організацій у суспільстві та виступає противагою влади, що контролює управління. Таким чином створюється суспільний інтерес, рефлексія та соціальна легітимність [22].
Розширюючи уявлення про функціональну специфіку стратегічних комунікацій, зазначимо їх спрямування на інформування суспільства про майбутні політичні дії або ж про вже втілені у житя заходи. Обов'язковою умовою такої діяльності $\epsilon$ прозорість і оперативність засобів масової інформації як в офіційних джерелах інформації, так і в соціальних мережах (див. детальніше [23]). При цьому стратегія - це те, що політики або члени організації створюють, а потім втілюють у життя. В сучасному глобальному суспільстві людство часто зіштовхується 3 невдоволеністю, економічними проблемами, напругою, парадоксами та суперечностями. Дослідники соціальних комунікацій М. Марчіорі і В. Булгачов наголошують на тому, що стратегічний підхід повинен спиратися не на замовчування проблем та відхід від них, а, навпаки, на їх прийняття, підвищення знань про них, надання їм характеристик та подальше керування ними за допомогою комунікаційної мети [24].

\section{3. Обговорення}

Наведені характеристики стратегічних комунікацій, хоча й зародилися у військових інституціях, однією з головних цілей визначають національні інтереси та залучення цільової аудиторії. При цьому стратегічні комунікації як на локальному, так і на державному рівні, у військовій та цивільній сфері мають подібні ознаки. Повна ідентичність, звісно, неможлива, через специфічність структур, але навіть у мілітаризованій сфері стратегічних комунікацій ідеологічний вплив виходить на перше місце.

Зважаючи на розмитість поняття «стратегічних комунікацій», пропонуємо у якості базової дефініції тлумачення Крістофера Пола (2011): «стратегічні комунікації - узгоджені інформаційні повідомлення і дії з метою впливу на аудиторію та просування національних інтересів» $[25$, с. 256]. При цьому, на наш погляд, варто розширити визначення до впливу та переконання у визначенні національних, політичних, організаційних та стратегічних цілей з метою покращення сприйняття та розуміння інформації, образів та дій, від яких залежить підтримка керівних рішень у суспільстві, оскільки стратегічні комунікації залежать від комунікативного змісту повідомлень, реальних дій, політики тощо.

\section{4. Висновок}

Стратегічні комунікації - це комплексне понятя, що включає в себе локальний, регіональний, державний та міждержавний рівні. Їх головним завданням $€$ підвищення ефективності промисловості, досягнення економічної та політичної стабільності, підвищення рівня культури шляхом досягнення якісної взаємодії між керівництвом держави та її народом за допомогою каналів просування відповідних ідей. Інформаційна політика, засоби зв'язків із громадськістю, публічна дипломатія, психологічні маніпуляції, інформаційні заходи - все це елементи стратегічних комунікацій, головною метою яких $\epsilon$ розширення аудиторії з метою активнішого просування національних ідей відповідно до прийнятої стратегії. 


\section{Список бібліографічних посилань}

1. A Global Strategy for the European Union's Foreign and Security Policy. 2016. URL: http://eeas.europa.eu/archives/docs/ top_stories/pdf/eugs_review_web.pdf (дата звернення: 22.11.2019).

2. Ліпкан В. А., Сопілко І. М., Кір'ян В. О. Правові засади розвитку інформаційного суспільства в Україні: монографія / за ред. В. А. Ліпкана. Київ : ФОП О. С. Ліпкан. 2015. 664 с.

3. Дорожня карта Партнерства у сфері стратегічних комунікацій між Радою національної безпеки і оборони України та Міжнародним секретаріатом HATO. 2016. URL: https://mfa.gov.ua/mediafiles/sites/nato/files/Roadmap_Ukr.pdf (дата звернення: 22.11.19).

4. Указ Президента України №555 «Про рішення Ради національної безпеки і оборони України від 2 вересня 2015». 2015. URL: https://zakon3.rada.gov.ua/laws /show/555/2015 (дата звернення: 25.11.19).

5. Стратегічні комунікації в умовах гібридної війни. Організатори, Весняна Академія НАТО, Центр інформації. 2016. URL: http://kunews.knu.ua/vesnyana-akademiya-nato-2016stratcomknu/ (дата звернення: 25.11.19).

6. Дубов Д. М. Стратегічні комунікації: проблеми концептуалізації та практичної реалізації. Політика 1. Серія: Cотратегічні комунікації. 2016. № 4 (41). С. 9-23. URL http://ippi.org.ua/sites/default/files/dubov.pdf (дата звернення: 26.11.19).

7. Hallahan K., Holtzhausen D., van Ruler B., Verčič D. \& Sriramesh K. Defining Strategic Communication. International Journal of Strategic Communication. 2007. Vol. 35. P. 3-5. doi: 10.1080/15531180701285244.

8. Toledano M., Dialogue, Strategic communication, and ethical public relations: Lessons from Martin Buber's political activism. Public Relations Review, 2018.Vol. 44. No. 1. P. 131-141. doi: 10.1016/j.pubrev.2017.09.009.

9. Hamilton B. Persuasion and Power: The Art of Strategic Communication. Political Science Quarterly. 2013. 128(4). P. 780781. doi: $10.1002 /$ polq.12112

10. Почепцов Г. Г. Стратегічні комунікації: стратегічні комунікації в політиці, бізнесі і державному управлінні. Київ : Альтерпрес, 2008. 216 с.

11. Баровська А. Стратегічні комунікації: досвід НАТО. Cmратегічні пріоритети. 2015. № 1 (34). С. 147-151. URL: http://sp.niss.gov.ua/content/articles/files/24-1436781085.pdf (дата звернення: 27.11.19).

12. Соловйов С. Г. Основні характеристики стратегічних комунікацій. Вісник Національного університету цивільного захисту України. Серія : Державне управління. 2016. Вип. 1. C. $165-170$.

13. Кушнір О. В. Поняття та сутність стратегічних комунікацій у сучасному українському державотворенні. Право $і$ суспільство. 2016. № 6. С. 27-31.

14. U.S. National Strategy for Public Diplomacy and Strategic Communication. 2007. URL: https://2001-2009.state.gov/ documents/organization/87427.pdf (дата звернення: 27.11.19).

15. National framework for strategic communication. Report of the Federal government. 2010. URL: https://www.hsdl.org/ ?abstract\&did=27301 (дата звернення: 27.11.19).

16. The President's National Framework for Strategic Communication (and Public Diplomacy) for 2012. URL: https://mountainrunner.us/2012/03/national-framework-

strategic-communication-public-diplomacy/ (дата звернення: 27.11.19).

17. Remarks by the President in State of the Union Address. 2015. URL: https://obamawhitehouse.archives.gov/the-press-
office/2015/01/20/remarks-president-state-union-address-January -20-2015 (дата звернення: 28.11.19).

18. Cornish P., Lindley-French J. \& Yorke C. Strategic Communications and National Strategy. Chatham House. London, 2011. URL: https://www.chathamhouse.org/sites/default/ files/r0911es-stratcomms.pdf (дата звернення: 28.11.19).

19. Thomas G. F., \& Stephens K. J. An Introduction to Strategic Communication. International Journal of Business Communication, 2014. 52(1). P. 3-11. doi: 10.1177/ 2329488414560469.

20. Reding A., Weed K., Ghez J. NATO's Strategic Communications concept and its relevance for France. 2010. URL: https://www.rand.org/pubs/technical_reports/TR855z2.html (дата звернення: 10.10.19).

21. Lange-lonatamishvili E., Svetoka S. Strategic communications and social media in the Russia Ukraine conflict / K. Geers. Cyber War in Perspective: Russian Aggression against Ukraine. Tallinn : NATO CCD COE Publications. 2015. P. 103-113.

22. Schall M. A Communication-Rules Approach to Organizational Culture. Administrative Science Quarterly. 1983. Vol.28. No.4. P. 557-581. doi: 10.2307/2393009.

23. Bentele G., Nothhaft H. Strategic Communication and the Public Sphere from a European Perspective. International Journal of Strategic Communication. 2010. Vol. 4. No. 2. P. 93-116. doi: 10.1080/15531181003701954.

24. Marchiori M., Bulgacov S. Strategy as communicational practice in organizations. International Journal of Strategic Communication. 2012. Vol. 6. No. 3. P. 199-211. doi: 10.1080/ 1553118X.2012.654550.

25. Paul C. Strategic Communication: origins, concept, and current debates. Santa Barbara : Praeger, 2011. 256 p.

\section{References}

1. European Union Global Strategy (2016) A Global Strategy for the European Union's Foreign and Security Policy. Available at: http://eeas.europa.eu/archives/docs/top_stories/pdf/eugs_ review_web.pdf (Accessed: 22 November 2019).

2. Lipkan, V., Sopilko, I., Kiryan, V. (2015) Legal bases of development of information society in Ukraine. Monograph. Kiev: O.S. Lippan.

3. Strategic Communication Partnership Roadmap between the National Security and Defense Council of Ukraine and the NATO International Secretariat (2016) Available at: https://mfa.gov.ua/mediafiles/sites/nato/files/Roadmap_Ukr.pdf (Accessed: 22 November 2019).

4. Presidential Decree No. 555 (2015) On the Decision of the National Security and Defense Council of Ukraine from 2 September 2015". Available at: https://zakon3.rada.gov.ua/laws /show / 555/2015 (Accessed: 25 November 2019).

5. Strategic communications in a hybrid war (2016) Organizers, NATO Spring Academy, Information Center. Available at: http://kunews.knu.ua/vesnyana-akademiya-nato-2016stratcomknu/ (Accessed: 27 November 19).

6. Dubov, D. (2016) "Strategic communications: problems of conceptualization and practical implementation". Policy 1: Strategic Communications, 41(4), pp. 9-23. Available at: http://ippi.org.ua/sites/default/files/dubov.pdf (Accessed: 26 November 2019).

7. Hallahan, K., Holtzhausen, D., van Ruler, B., Vercic, D. \& Sriramesh, K. (2007) "Defining Strategic Communication", International Journal of Strategic Communication, 35, pp. 3-5. doi: 10.1080/15531180701285244.

8. Toledano, M. (2018), “Dialogue, Strategic Communication and Ethical Public Relations: Lessons from Martin Buber's Political Activism", Public Relations Review, 44(1), pp. 131-141. doi: 10.1016/j.pubrev.2017.09.009. 
9. Hamilton, B. (2012) "Persuasion and Power: The Art of Strategic Communication", Political Science Quarterly, 128(4), pp. 780-781. doi: $10.1002 /$ polq.12112.

10. Pocheptsov, G. (2008) Strategic communications: strategic communications in politics, business and public administration. Kiev: Alterpress.

11. Barovskaya, A. (2015) "Strategic Communications: NATO Experience", Strategic priorities, 1(34), pp. 147-151. Available at: http://sp.niss.gov.ua/content/articles/files/24-1436781085.pdf (Accessed: 27 November 2019).

12. Solovyov, S. (2016) "Basic Characteristics of Strategic Communications", Bulletin of the National University of Civil Defense of Ukraine, Series: Public Administration, 1, pp. 165-170.

13. Kushnir, O. (2016) "The concept and essence of strategic communications in modern Ukrainian state-making", Law and Society, 6, pp. 27-31.

14. U.S. National Strategy for Public Diplomacy and Strategic Communication (2007) Available at: https://2001-2009.state.gov/ documents/organization/87427.pdf (Accessed: 27 November 2019).

15. National framework for strategic communication (2010) Report of the Federal Government. Available at: https://www.hsdl.org/?abstract\&did=27301 (Accessed: 27 November 2019).

16. The President's National Framework for Strategic Communication (and Public Diplomacy) (2012) Available at: https://mountainrunner.us/2012/03/national-frameworkstrategic-communication-public-diplomacy/ (Accessed: 27 November 2019).

17. Remarks by the President in State of the Union Address (2015) Available at: https://obamawhitehouse.archives.gov/ the- press-office/2015/01/20/remarks-president-state-union-addressJanuary-20-2015 (Accessed: 27 November 2019).

18. Cornish, P., Lindley-French, J., \& Yorke, C. (2011) "Strategic Communications and National Strategy", Chatham House, London. Available at: https://www.chathamhouse.org/ sites/default/files/r0911es-stratcomms.pdf (Accessed: 27 November 2019).

19. Thomas, G., \& Stephens, K. (2014) "An Introduction to Strategic Communication", International Journal of Business Communication, 52(1), pp. 3-11. doi: 10.1177/ 2329488414560469.

20. Reding, A., Weed, K., \& Ghez, J. (2010) NATO's Strategic Communications Concept and Its Importance for France. Available at:https://www.rand.org/pubs/technical_reports/ TR855z2.html (Downloaded: 10 October 2019).

21. Lange-lonatamishvili, E., \& Svetoka, S. (2015) "Strategic communications and social media in the Russia Ukraine conflict", in: Geers, K. (ed.), Cyber War in Perspective: Russian Aggression against Ukraine. Tallinn: NATO CCD COE Publications, pp. 103-113.

22. Schall, M. (1983) "A Communication-Rules Approach to Organizational Culture", Administrative Science Quarterly, 28(4), p. 557-581. doi: 10.2307/2393009.

23. Bentele, G. \& Nothhaft, H. (2010) "Strategic Communication and the Public Sphere from a European Perspective", International Journal of Strategic Communication, 4(2), pp. 93-116. doi: 10.1080/15531181003701954.

24. Marchiori, M. \& Bulgacov, S. (2012) "Strategy as communicative practice in organizations", International Journal of Strategic Communication, 6(3), pp. 199-211. doi: 10.1080/1553118X.2012.654550.

25. Paul, C. (2011) Strategic Communication: origins, concept, and current debates. Santa Barbara: Praeger.

\section{Tereshchenia 0. Strategic communications in scientific and theoretical discourse}

The concept of "strategic communications" has recently become popular in the field of social communications. In the early 2000 s the term was used mainly in the military, political and scientific circles of the USA and some European countries. Now there are many studies of strategic communications. This concept is being actively used in scientific works and official regulatory documents both in the world and in Ukraine. At the same time, there is still no generally accepted definition of what strategic com munications are, how this system complex should be used in special works, and what is their goal. This creates uncertainty and discussions around even the basic components of this theoretical and practical phenomenon. The article considers the existing concepts of strategic communications, the main functions and components of the concept, analyzes individual considerations of researchers and offers a generalized interpretation of the term. The basic approaches to the definition of strategic communications are systematized, their characteristics are highlighted. The individual tasks that need to be resolved while preparing an effective strategic communications program are emphasized. It is determined that the elements of strategic communications consist of the objects of strategy, communication theory and methodology. It is proved that an effective system of strategic communications is a relevant indicator of the success of the organization and implementation of the political program, it contributes to the development of institutions and guarantees public support in times of crisis. It is noted that one of the main foundations of strategic communications is the promotion of the interests of the state, organization or company, and the lack of a systematic approach, the inefficient activities of the main participants in the process and the unstable implementation of organizational or political strategic decisions reduce the influence of the organization mechanism or public administration as a whole.

Keywords: strategic communications; social communications; scientific discourse. 